(C) Copyright, Princeton University Press. No part of this book may be distributed, posted, or reproduced in any form by digital or mechanical means without prior written permission of the publisher.

\title{
1
}

\section{A Brief Introduction to Student Loans}

\author{
Student borrowing to pay the costs of postsecond- \\ ary education has skyrocketed in the last decade.... \\ Growing student indebtedness has raised questions \\ about the implications of debt burdens for the \\ national economy, for the individual well-being of \\ borrowers, for equality of access to higher educa- \\ tion, and even for the educational process itself. ${ }^{1}$
}

These words capture the prevailing public narrative around student loan debt, with increasing borrowing levels raising alarm among students, parents, policymakers, and the public. But these concerns are not new-the passage above is from a 1986 report commissioned by the Joint Economic Committee in the U.S. Congress. As of that writing, annual student borrowing had quintupled from a decade prior, to about $\$ 22$ billion in today's dollars, or $\$ 2,400$ per student.

Those borrowing levels pale in comparison to those seen today. Over the course of the following three decades, annual borrowing quintupled yet again, to more than $\$ 100$ billion, or about $\$ 7,000$ per student. ${ }^{2}$ The seemingly never-ending increases in debt levels have aroused similar concerns about the impact of debt on borrowers and the nation. Student loans have become a scapegoat for a host of problems ranging from 
(C) Copyright, Princeton University Press. No part of this book may be distributed, posted, or reproduced in any form by digital or mechanical means without prior written permission of the publisher.

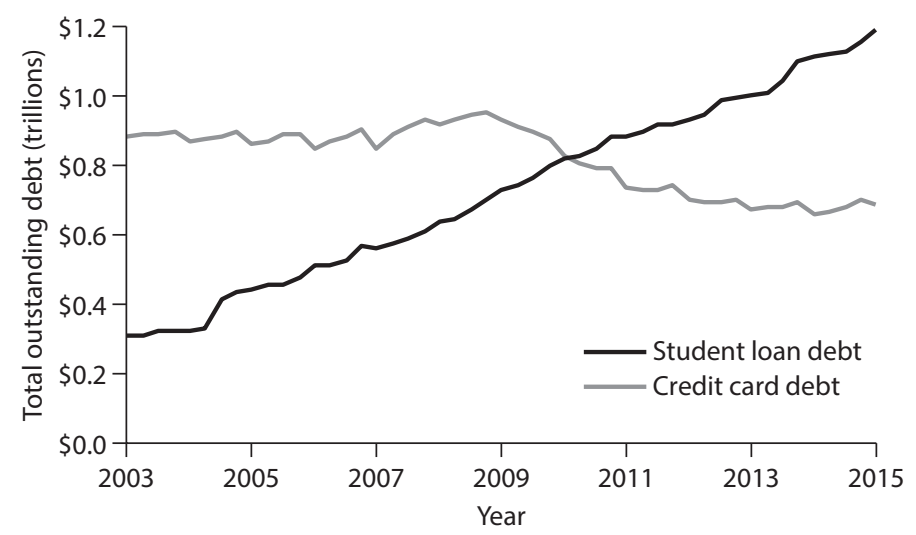

Figure 1.1. Total outstanding student loan debt and credit card debt, 2003-15 (\$ Trillions)

Source: Federal Reserve Bank of New York 2015 Q1 Report. Notes: 2014 dollars.

a weak economic recovery to delayed marriage and childbearing to decreases in entrepreneurship. ${ }^{3}$

The last decade has seen especially large increases in student debt, with two key moments attracting significant attention: total outstanding student debt surpassed total credit card debt in 2010 and then passed the \$1 trillion mark in 2013, according to data assembled by the Federal Reserve Bank of New York (figure 1.1). ${ }^{4}$ Other estimates date the passing of the $\$ 1$ trillion mark as early as late $2011 .^{5}$

The opening quote, drawn from a 1986 report titled "Student Loans: Are They Overburdening a Generation?”, makes clear that fears of a student loan crisis are not new. But public attention to student loan debt has surged in recent years. Figure 1.2 shows that coverage of this topic in the New York Times reached an all-time high in 2014, and that in recent years it 
(C) Copyright, Princeton University Press. No part of this book may be distributed, posted, or reproduced in any form by digital or mechanical means without prior written permission of the publisher.

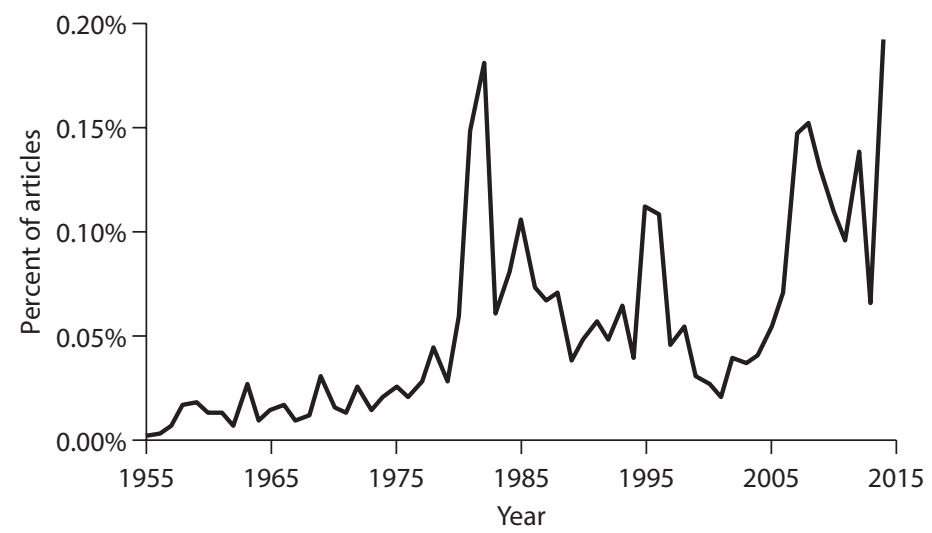

Figure 1.2. Percentage of New York Times articles mentioning student loans, 1955-2014 Source: Chronicle (http://chronicle.nytlabs.com/)

has gained levels of attention last seen in the early 1980s, when crackdowns on delinquent borrowers and political fights over the loan program garnered public attention. ${ }^{6}$

Perhaps surprisingly, the 1986 report commissioned by the U.S. Congress found little evidence to support all of the hysteria around student loans:

[S] ome frequently-heard concerns about student borrowing are not supported by the evidence available to date, although the paucity of good data and studies make it unwise to dismiss these concerns out of hand. In particular, it is not yet clear that high debt levels are causing serious problems for many students; that educational, career, and personal decisions are being affected by indebtedness; or that the growth in student borrowing poses a threat to the national economy. ${ }^{7}$ 
(C) Copyright, Princeton University Press. No part of this book may be distributed, posted, or reproduced in any form by digital or mechanical means without prior written permission of the publisher.

The purpose of this book is to examine whether reality has caught up with the hype and fear generated by student loans. In short, we find that it hasn't. There is no evidence of a widespread, systemic student loan crisis, in which the typical borrower is buried in debt for a college education that did not pay off. The crisis that permeates public discussion is a manufactured narrative based largely on anecdotes, speculation, shoddy research, and inappropriate framing of the issue.

The problem with this false narrative is that it makes it harder to fix the real problems in student lending. There is not a single student loan crisis, but there are many crises, ranging from the fact that most students have no more than a vague idea of how much they've borrowed, to the hundreds of thousands of borrowers needlessly defaulting on their student loans, to the pockets of students who are making decisions that lead to predictably bad completion and repayment outcomes. These are pressing problems that need solutions, but unfortunately the myth of a broad-based loan crisis has led to well-intentioned but poorly targeted policy proposals aimed at all borrowers, which work to the benefit of those with the most debt rather than those in the greatest distress.

Accurately assessing the state of student lending today requires an understanding of why student loans exist in the first place, and why they are largely made by the federal government. The remainder of this chapter develops this rationale, which provides a set of basic principles that are useful to keep in mind as we examine borrowing levels (chapter 2), trends in borrowing over time (chapter 3), the financial well-being of 
(C) Copyright, Princeton University Press. No part of this book may be distributed, posted, or reproduced in any form by digital or mechanical means without prior written permission of the publisher.

borrowers (chapter 4), and the possible impact of education debt on the economy (chapter 5).

We return to this set of ideas in chapter 6 by viewing the facts about student lending in the United States through the lens introduced in this chapter. The stark contrast between how student lending is supposed to work and how it works today identifies several important problems facing student lending in the United States. We conclude in chapter 7 by proposing a comprehensive set of reforms to bring reality closer to this ideal.

\section{HOW STUDENT LOANS ARE DIFFERENT}

The national dialogue about student debt often compares education loans to credit card debt. In fact, there was quite a stir in the media when total outstanding education debt surpassed total outstanding credit card debt. But it's important, for both individuals and policymakers, to recognize that student debt is different. First, let's go back to basics.

What is debt? Debt is a tool that enables an individual to consume more today by taking money from her future self. Of course, we can't travel through time to interact with our future selves, so we rely on a third party, the lender, to make this transaction possible. In practice, a loan is an agreement between a borrower and a lender, but it's important to bear in mind that a loan actually is a transaction between an individual and her future self. 
(C) Copyright, Princeton University Press. No part of this book may be distributed, posted, or reproduced in any form by digital or mechanical means without prior written permission of the publisher.

There are a number of instances when taking on debt is a reasonable thing to do. For example, it makes sense to borrow when you expect that your future self will be much wealthier than your present self. It also makes sense to borrow when you make a purchase that will benefit your future self. For instance, the price tag for a new car is due when you drive the car off the lot, but the benefits of owning that car will be enjoyed over a number of years. The prevalence of borrowing to finance car and home purchases suggests that many people are comfortable using debt in this way.

But we're all familiar with the fact that many people also use debt in less constructive ways. In particular, many fall into the habit of using debt, particularly credit cards, to purchase items that they simply cannot afford-not now and not in the future. This use of debt essentially amounts to postponing the inevitable of having to cut back. We've all been warned against the pitfall of using debt to finance purchases that we can't really afford, but rhetoric would suggest that it is still a prevalent behavior.

Student debt, however, is different. Financing a college degree does not amount to the postponement of an expense that one simply cannot afford. Instead, it's a means for transferring wealth from a future period of relative prosperity to the present. Not only does this allow consumers to smooth their consumption over time, as economists put it, but the debt in itself is what generates the opportunity for the heightened future prosperity. This is to say that student debt finances an investment that pays dividends in the future rather than simply consumption that pays dividends in the present. 
(C) Copyright, Princeton University Press. No part of this book may be distributed, posted, or reproduced in any form by digital or mechanical means without prior written permission of the publisher.

Many big-ticket purchases combine both consumption and investment. A prominent example is home buying, for which most Americans use mortgage financing, typically over 30 years. Home ownership is consumption if the owner lives in the home. More expensive homes generally imply greater consumption, as the owner pays more for mortgage, taxes, and the like. But houses also potentially increase in value over time, so they are also an investment. Of course buying a home based on expectations about its future value can lead to trouble, as the recent mortgage crisis made clear.

Education, like a home, is a combination of investment and consumption. College is an investment because it is expected to increase students' future incomes, on average. The consumption component of college includes all of the costs that are not strictly part of the experience that leads to a higher future income. The part of tuition that pays for beautiful leafy campuses, extracurricular activities, student centers, and athletics facilities are consumption to the extent that these expenditures do not increase what students can expect to earn after they graduate. The particular combination of investment and consumption obviously varies widely across campuses, with some looking like summer camps that offer college classes and others offering a more bare-bones experience.

In practice, it is difficult or even impossible to parse educational services in this way. Many parts of an educational experience could be classified as both consumption and investment. For example, extracurricular activities might combine learning and enjoyment. Even when it is clear that a particular aspect of college won't yield financial dividends in the future, 
(C) Copyright, Princeton University Press. No part of this book may be distributed, posted, or reproduced in any form by digital or mechanical means without prior written permission of the publisher.

students generally can't refuse to pay for it and generally have no way of knowing how much of their tuition it represents.

It is still worthwhile to think about the distinction between consumption and investment when one is shopping for college because colleges vary in the consumption amenities that they offer. Prospective students can refuse to pay for fancy athletic facilities and dormitories by attending a lower-priced campus that offers fewer such amenities. Students should think of student loans that pay for the consumption part of the college experience in the same way they think about credit card debt. It enables them to enjoy something right away, but they will have to pay for it later. ${ }^{8}$ Education loans taken out to finance another person's education can also be seen in a similar light, since the borrower may not have any claim on the future earnings of the loan recipient. ${ }^{9}$

\section{WHY GOVERNMENT INVOLVEMENT IN HIGHER EDUCATION?}

A number of factors in the arena of higher education contribute to what economists call a market failure. This means that the natural conditions are such that the market outcomethe outcome that would occur without any government intervention-is worse than the outcome that could be achieved with the help of some well-crafted policy interventions. In the absence of government intervention, too few students would enroll in college and complete degrees, which would reduce the capacity for productivity and innovation in the nation's economy. 
(C) Copyright, Princeton University Press. No part of this book may be distributed, posted, or reproduced in any form by digital or mechanical means without prior written permission of the publisher.

One important driver of this market failure in higher education comes from the fact that there are significant public returns to investments in higher education. This means that if individuals and the market were left to their own devices, public investment in higher education would be less than optimal from a societal perspective. Government subsidies to higher education serve to ensure that students from all walks of life have access to the opportunity afforded by higher education, but also serve to encourage higher levels of educational attainment across the board.

A second key failure in the market for higher education financing is the fact that student loans finance the purchase of a service, not a good. A loan used to buy a car or a house is guaranteed in part by the good itself. If the borrower fails to pay, the lender can repossess the car or foreclose on the house. There is no such collateral for a student loan. If the student fails to pay, the lender can try to get them to make good on their promise to pay, but there is no tangible object that they can take to help cover their loss on the loan gone bad. A student who wants to borrow to go to college is asking to be given money based on a promise to pay out of future income, with no collateral for the lender to take if the borrower fails to pay. A loan based on future income is riskier than a loan based on current income, and a loan without collateral is riskier than a loan with one. As a result, lenders face greater risk in making student loans, and have to charge higher prices (interest rates) to make up for it.

The upshot is that the private market will not make student loans available on attractive terms to as many borrowers as society would like to see able to borrow for college. This idea 
(C) Copyright, Princeton University Press. No part of this book may be distributed, posted, or reproduced in any form by digital or mechanical means without prior written permission of the publisher.

goes back to at least Milton Friedman, who in 1955 wrote about the greater risk of lending for "human capital" (education and training) than for "physical capital," and about the risk inherent in lending based on expectations of future income. ${ }^{10}$ Friedman's proposed solution to this problem, in which borrowers make payments based on their incomes, is an idea called income share agreements that we'll return to in chapter 7.

Government intervention in the market for higher education and student loans is entirely justified on the grounds of these market failures, but it is also the case that the government has some comparative advantage when it comes to administering student loans. For instance, the government has tools to enforce repayment that the private sector does not have, such as the ability to take delinquent borrowers' wages and tax refunds. Additionally, the government can withstand a riskier loan portfolio because, unlike private lenders, it doesn't need to worry about going out of business.

\section{THE IDEAL STUDENT LENDING SYSTEM}

What does the rationale for student loans in general, and government loans in particular, tell us about what a wellfunctioning student lending system should look like? We identify five main features, all of which are predicated on the notion that borrowing for college should be treated as an investment decision. Education is about much more than financial success, but it should be thought of primarily as an investment 
(C) Copyright, Princeton University Press. No part of this book may be distributed, posted, or reproduced in any form by digital or mechanical means without prior written permission of the publisher.

for the purposes of making financial decisions that have longterm consequences for borrowers and society.

First, student loans should finance investments and not consumption to the greatest extent possible. This is especially true of government loans, for which taxpayers are taking on risk. Students and parents who want to borrow for consumption can do that in the private market, but that activity should be kept separate from what we are calling "student loans."

Second, students and their families should make wellinformed decisions when determining how much to borrow. They should use the best available information on how much they will pay for their education, the chances that they will successfully earn a degree, and the income that they can expect after graduation. Taking on student debt without carefully considering these factors would be like borrowing to start a business without any idea about whether it will be successful.

Third, students should be protected from the risk inherent in borrowing to pay for their education. Students should not be allowed to make predictably bad decisions, such as borrowing to earn a degree with very low success rates or labor market prospects. In other words, students should not be able to take on significant debt if it is obvious from the outset that they will never be able to pay it back.

Fourth, not all bad loans are the result of predictably bad decisions. Some students simply get unlucky, such as by graduating in a bad economy or realizing that their chosen field is not a good fit for them (and then switching to a field with lower earnings despite having borrowed expecting higher 
(C) Copyright, Princeton University Press. No part of this book may be distributed, posted, or reproduced in any form by digital or mechanical means without prior written permission of the publisher.

earnings). A well-functioning lending system will protect students from this unpredictable risk.

Finally, government student lending programs should be cost-effective and protect taxpayers to the greatest extent possible. Just because the government is in a stronger position to make risky loans than the private sector doesn't mean it should do so at every opportunity. The government has a responsibility to balance its role as a steward of taxpayer dollars with its mission to spend those dollars to further the social good.

The chapters that follow show how the student lending system in the United States falls short on all of these dimensions. At the same time, the average college student is making a good investment that will more than pay for itself over the student's lifetime. The rest of this book reconciles the overheated rhetoric of a systemic student loan crisis with the reality that student lending suffers from real problems. These problems are too often lost in the prevailing public narrative about student debt, but solving them would make higher education more efficient and fair for all Americans. 